\title{
Palaeo-geoecological significance of Pleistocene trees in the Lluta Valley, Atacama Desert
}

Heinz Veit, ${ }^{1 *}$ Jan-Hendrik May, ${ }^{2}$ Andrea Madella, ${ }^{3}$ Romain Delunel, ${ }^{3}$ Fritz Schlunegger, ${ }^{3}$ Sönke Szidat ${ }^{4}$ and José M. Capriles ${ }^{5,6}$

${ }^{1}$ Institute of Geography, University of Bern, Switzerland

${ }^{2}$ Institute of Earth and Environmental Sciences - Geology, Albert-Ludwigs-Universität Freiburg, Germany

${ }^{3}$ Geological Institute, University of Bern, Switzerland

${ }^{4}$ Department of Chemistry and Biochemistry \& Oeschger Centre for Climate Change Research, University of Bern, Switzerland

${ }^{5}$ Departamento de Antropología, Universidad de Tarapacá, Arica, Chile

${ }^{6}$ Department of Anthropology, The Pennsylvania State University, PA 16802, USA

*Correspondence: Heinz Veit, as above.

E-mail: veit@giub.unibe.ch

Running head: PLEISTOCENE TREES IN THE LLUTA VALLEY

Graphical abstractJQS 2857 Graphics sizing and other information

Fig. 1. Full page depth with caption below

Fig. 2. Full page depth with caption below

Fig. 3. Full page width $(17.6 \mathrm{~cm})$

Fig. 4. $3 / 4$ of full page width $(13.2 \mathrm{~cm})$

Fig. 5. 2/3 page width $(11.7 \mathrm{~cm})$, caption at the side

Number of Tables: 2

Supporting information. None. 

Please
send
the
proofs
to
submitting
Editor
(Dr
Joe
Licciardi
(Email:
joe.licciardi@unh.edu)

Abstract

In the Lluta Valley, northern Chile, climate is hyperarid and vegetation is restricted to the valley floors and lowermost footslopes. Fossil tree trunks and leaves of predominantly Escallonia angustifolia, however, are abundant up to $\sim 15 \mathrm{~m}$ above the present valley floor, where they are intercalated with slope deposits, reflecting higher water levels in the past. A total of 17 samples have been radiocarbon dated, yielding ages between 38 and 15k cal a BP. The youngest ages of $15.4 \mathrm{k}$ cal a BP are interpreted as reflecting the beginning of river incision and lowering of the valley floor, impeding the further growth of trees at higher parts of the slopes. The most plausible scenario for this observation is intensified river incision after $15.4 \mathrm{k}$ cal a BP due to increased stream power and runoff from the Rio Lluta headwaters in the Western Cordillera and Altiplano corresponding to the highstand of the Tauca and CAPE wet phase.

KEYWORDS: Atacama desert; climate change; fluvial dynamics; late Pleistocene; northern Chile.

\section{Introduction}

The Atacama Desert in northern Chile is one of the driest deserts on earth. Rainfall along the coast between Arica and Iquique is $\sim 1$ mm a ${ }^{-1}$ Schulz et $_{\text {al. }}$, 2011). Cosmogenic ${ }^{21} \mathrm{Ne}$ exposure dates on surfaces in Quebrada Tiliviche near Pisagua (19 $\left.35^{\prime} \mathrm{S}\right)$ indicate the onset of extreme hyper-aridity probably as early as 25-22 Ma (Dunai et al., 2005). Hyperarid conditions might have persisted through most of the Neogene as the Andes reached their current elevation around $15 \mathrm{Ma}$, creating the pronounced rain-shadow effect still in place today (Alpers and Brimhall, 1988; Houston and Hartley, 2003), even though ages around $10 \mathrm{Ma}$ have also been proposed (Jordan et al., 2014). As a consequence, the landscape in the Atacama Desert is characterized by very smooth slopes and interfluves which do not sustain noteworthy plant growth, and are characterized by extremely low erosion rates (Kober et al., 2007). In contrast, the main rivers in northern Chile, such as the Río Lluta, reach the Pacific via canyon-like valleys (Figs 1 and 2a). Downcutting via headward migration of erosional fronts (i.e. knickzones) probably commenced at $~ 8-11$ Ma in response to surface uplift (García and Hérail, 2005; Schlunegger et al., 2006; Schildgen et al., 2007, 2010; Thouret et al., 2007; García et al., 2011), and had lowered the valley floor to near-modern elevations by 2.7 Ma in proximity to the Pacific coast, as evidenced by the Lauca Ignimbrite deposits (Schröder and Wörner, 1996; Uhlig, 1999; Schlunegger et al., 2006; García et al., 2011). This implies relative long-term stability of the valley floor elevation along the graded river reach beneath the knickzone (Fig. 1e), and dominant sediment bypass in wide braided river channels and floodplains. In this setting, vegetation is restricted to the lowermost footslopes and marginal valley floors, representing modern 'treelines' (Fig. 2a). Fossil tree trunks and leaves, however, are abundant up to $15-20 \mathrm{~m}$ above the present valley floor of the Lluta Valley in northern Chile, where they are intercalated with slope deposits, suggesting past changes in water availability and humidity. Therefore, these deposits may provide new information on changes in discharge and/or sediment supplies over late Quaternary timescales. Here we present a comprehensive radiocarbon-based chronology for these stratified slope deposits in the Lluta Valley, consider potential mechanisms of their formation, and discuss their palaeoclimatic and tectonic significance. 


\section{Study area}

Geologically, northern Chile is characterized (from west to east) by a Coastal Cordillera, Central Depression, Precordillera and the Western Cordillera (Fig. 1b). Directly north of Arica, the Coastal Cordillera is completely absent, whereas south of Arica it is characterized by a steep escarpment and up to 1000-mhigh cliffs, deeply incised by some of the major rivers in northern Chile (Fig. 1b,c). With their headwaters in the Western Cordillera of the Andes, these rivers reach the Pacific via canyon-like valleys such as the Quebrada de Camarones, Quebrada de Vitor, Quebrada de Azapa or the Valle de Lluta which have incised up to $1000 \mathrm{~m}$ into the surrounding Tertiary pediments and peneplains of the Precordillera and Central Depression (Fig. 1). Further south, between $\sim 19^{\circ} 30^{\prime} \mathrm{S}$ and $26^{\circ} 30^{\prime} \mathrm{S}$, most rivers are endorheic and terminate in the hyperarid Atacama Desert. Climatic conditions in northern Chile and the Atacama region are generally hyperarid, and are characterized by a strong meridional gradient in annual precipitation with $0.4 \mathrm{~mm}$ at the coast to $237 \mathrm{~mm}$ at Putre (3650 m a.s.1.) and values of $>350 \mathrm{~mm}$ in the highest parts of the catchment (DGA, 2004). The region's hyperaridity owes its existence to a combination of: (i) the extreme rainshadow effect of the high Andes, blocking advection of tropical/subtropical moisture from the east; (ii) limited influence of winter storm tracks from the south due to the presence of the semi-permanent South Pacific Anticyclone; and (iii) the generation of a temperature inversion at $\sim 1000 \mathrm{~m}$ by the cold, north-flowing Humboldt Current that limits the inland (upslope) penetration of Pacific moisture. Precipitation variability in both summer and winter is modulated primarily by Pacific sea surface temperature gradients and the associated upper-air circulation anomalies (Vuille et al., 2000; Garreaud et al., 2003). A significant fraction of the inter-annual variability of summer precipitation is currently related to the El Niño Southern Oscillation (Vuille, 1999). Thus, wet summers on the Andean Altiplano are associated with an El Niño Southern Oscillation-related cooling of the tropical Pacific (i.e. La Niña phase). Rainfall and discharge maxima occur mainly during the 'Invierno Boliviano' (December-March; DGA, 2004; Houston, 2006) in relation to the South American Summer Monsoon system (Lenters and Cook, 1997; Schulz et al., 2011), which transports moisture from the Amazon lowlands over the Andes down to $2800 \mathrm{~m}$ a.s.l. on the western Andean slopes, but does not cause significant rainfall in the central Atacama (Rech et al., 2006).

The catchment of the Río Lluta comprises an area of $\sim 3400 \mathrm{~km}^{2}$, with a river length of approximately $150 \mathrm{~km}$ (Fig. 1c). The highest peaks in the upper catchment are the 'Nevados de Putre' (5861 m a.s.l), 'Volcán Tacora' (5988 m a.s.1.) and 'Volcán Tarapacá' (5860 m a.s.1.). The Lluta River originates in the Western Cordillera at an altitude of about $3900 \mathrm{~m}$ a.s.l. and reaches the Pacific Ocean $\sim 4 \mathrm{~km}$ north of Arica at $18^{\circ} 24^{\prime} 55^{\prime \prime} \mathrm{S}, 7^{\circ} 19^{\prime} 35^{\prime \prime} \mathrm{W}$ (Fig. 1c). Whereas a pediplain developed on top of the Coastal Cordillera during the Paleogene ('Tarapacá Pediplain'; Mortimer and Sarič, 1975), river incision in northern Chile commenced at $\sim 8-11 \mathrm{Ma}$ in response to surface uplift (García and Hérail, 2005; Schildgen et al., 2007, 2010; Thouret et al., 2007; García et al., 2011). In the Lluta Valley incision had lowered the valley floor nearly to modern elevations by $2.7 \mathrm{Ma}$, as evidenced by the Lauca Ignimbrite deposits (Schröder and Wörner, 1996; Uhlig, 1999; García et al., 2011). Today, the Lluta Valley long-profile exhibits a 30- km-long, steep and narrow knickzone of mixed bedrock-alluvial channel morphology, which divides the Lluta River into an upstream and downstream segment of wider valley floors (Fig. 1e). Beneath the knickzone, the valley floor is up to $1200 \mathrm{~m}$ wide, encompassing a gravelly braided river channel and variably wide floodplains. Only very few remnants of older terraces are visible, but they have not been studied up to now and their age and genesis are unknown. Today, the floodplain is subject to intensive irrigation and agricultural use (Fig. 2a). The Lluta River has incised 1-3 m into this valley bottom, which seems to have been the active floodplain for most of the Holocene. Apart from agriculture, Escallonia angustifolia and Schinus molle are the dominating trees of the riparian plant communities near the current valley floor. Schinus molle can live from groundwater, with root systems of 10-20 m in length, whereas Escallonia angustifolia needs surficial running water and humidity. Surface discharge along the Rio Lluta is highly seasonal and can reach mean monthly flows of $\sim 16 \mathrm{~m}^{3} \mathrm{~s}^{-1}$ in February at the Pacific coast (DGA, 2004), and sediment loads up to 1700 tonnes per day have been measured during peak flow episodes (Campos Ortega et al., 2007). The annual distribution of discharge is strongly controlled by precipitation in the Andean headwaters of the Lluta River in the Western Cordillera (Fig. 1c), which is 
mainly built up by volcanic and sedimentary sequences (García et al., 2011). In the Central Depression and the Precordillera, the geology is characterized by Oligo-Miocene sediments and ignimbrites (Azapa, Oxaya, El Diablo and Huaylas formations, Tobar et al., 1968; Seyfried et al., 1995; Uhlig, 1999; García et al., 2011). Uplift of the Precordillera has induced major landslides, and parts of the Oxaya Formation collapsed >2.5 Myr ago building up the large Lluta Collapse deposit (Seyfried et al., 1998; Wörner et al., 2002; Strasser and Schlunegger, 2005; García et al., 2011). All profiles presented here are situated in the area of the Lluta Collapse (Fig. 1c,d), east of Poconchile and along Chile's National Road $11\left(18^{\circ} 27^{\prime} 6^{\prime \prime} \mathrm{S}, 70^{\circ} 4^{\prime} 1^{\prime \prime} \mathrm{W} ; \pm 750 \mathrm{~m}\right.$ a.s.1.). Along this segment of the valley, profiles can be studied easily along road cuts. However, the fossil trunks and leaves exist in a far broader area, from the coast and the mouth of the Lluta River up to $>1000 \mathrm{~m}$ a.s.l. along the valley floor. Further upstream of our study area the main road soon leaves the valley and crosses to the southern Azapa Valley. The smaller road which continues in the Lluta catchment runs on the present valley floor. We concentrated our investigation on the easily accessible part with open profiles.

\section{Methods}

Fieldwork consisted of detailed investigation of road cut exposures in the lower slopes along the southern side of the Lluta Valley east of Poconchile (Fig. $1 \mathrm{c}, \mathrm{d})$. An exhaustive sampling campaign was conducted on the organic horizons situated at 30-50 km from the coast (Figs 2-4). As the up to 50-cm-thick leaf deposits could be identified as almost completely consisting of leaves of Escallonia angustifolia, no further in-depth study of the palaeovegetation was undertaken. Trunks, which are completely imbedded within the leaf deposits, were not identified botanically. Profiles of these slope sedimentary sequences were described in the field. Profile location as well as an approximate elevation were documented with a hand-held GPS. Organic layers, mostly leaves and trunks, were stratigraphically sampled at five locations for ${ }^{14} \mathrm{C}$ dating (Profiles $\mathrm{km} \mathrm{36.2,} \mathrm{km} \mathrm{36.5,} \mathrm{km} \mathrm{37.0,} \mathrm{km} 37.5$ and $\mathrm{km} \mathrm{37.7;} \mathrm{Table} \mathrm{1;} \mathrm{ten} \mathrm{samples),} \mathrm{and}$ were analysed at the radiocarbon laboratory of the Institute of Physics at the University of Bern. To check for spatial validity and chronological accuracy of these results, a set of additional samples was collected from exposures situated in a wider area (Profiles LVW-1, LVW-2, LVW-3, LVW-4, LVW-5, LVW-6 and LVW-7; Table 2; seven samples) and analysed with the accelerator mass spectrometer MICADAS at the LARA laboratory at the University of Bern (Szidat et al., 2014). All results were calibrated with CALIB version 7.0 (Stuiver and Reimer, 1993, 2011) and the SHcal13 calibration curve (Hogg et al., 2013). These dates are referred to as 'cal a BP' or ' $\mathrm{k}$ cal a BP'.

\section{Results}

The slopes along the Lluta Valley are very smooth and undissected without any sign of linear erosion (Fig. 2a). In the hyperarid setting of northern Chile, these slopes are the combined product of the slow salt- and gravity-related surficial displacement of material (salt-creep), granular flows, and the lack of linear fluvial erosion (Mortensen, 1927; Abele, 1987, 1990). These hillslope deposits are made up of well-sorted, horizontally stratified and cross-bedded sandy and coarser detritus, lacking a sedimentary matrix, with a thickening of the layers downslope. Stratification is on the order of millimetres, dipping parallel to the surface. These slope sediments are frequently intercalated with layers of fossil organic material such as trunks and leaves (Figs $2 \mathrm{~b}-\mathrm{d}$ and 3 ). Trunks and branches do not show signs of transport and are well preserved (Figs $2 \mathrm{~d}$ and $3 \mathrm{~d}$ ). Therefore, they are more or less in an in situ position. It is particularly in the surroundings of Poconchile where this organic material is nicely recognizable along road cuts. In one case the slope sediments have buried 
the Ah-horizon of a palaeosol (Fig. 2e). The fossil organic material reaches up to $\sim 9 \mathrm{~m}$ above the present distribution of living trees at the intersection of the modern valley floor and slopes (Fig. 3a), which is generally up to 11-15 m (exception: profile LVW-2 at $17.9 \mathrm{~m}$ and Profile LVW-7 at $20.3 \mathrm{~m}$ ) above the valley bottom. Further upslope, no trunks or leaves have been found. Most documented profiles contain several layers of organic material, reflecting an alternation of tree growth and sedimentation (Figs 2 and 4). All radiocarbon ages from these organic layers and a bAh horizon are summarized in Tables 1 and 2. The profiles documented in the photographs (Fig. 2) and sketches (Fig. 4) can be characterized as follows:

- At km 36.2 (Figs $2 \mathrm{c}$ and 4), leaves from a single organic layer at $~ 80 \mathrm{~cm}$ in the profile are dated to $23.9 \pm 0.1 \mathrm{k}$ cal a BP.

- The profile at $\mathrm{km} 36.5$ (Figs $2 \mathrm{~b}$ and 4 ) shows at least five organic layers and a layer of whitish volcanic ash. A wood fragment from the lowermost exposed organic layer at $250 \mathrm{~cm}$ below the surface yielded an age of $37.1 \pm 0.4 \mathrm{k}$ cal a BP. Two samples from leaf-dominated layers at 120 and $50 \mathrm{~cm}$ have ages of $28.9 \pm 0.1$ and $18.3 \pm 0.1 \mathrm{k} \mathrm{cal} \mathrm{a} \mathrm{BP}$, respectively. The uppermost $30 \mathrm{~cm}$ of the profile contains reeds, faecal pellets and abundant ceramics. The reed sample was dated to $0.5 \pm 0.01 \mathrm{k}$ cal a BP ( AD 1406-1439), thus reflecting the locally strong influence of pre-Colombian cultures in the Lluta Valley.

- At km 37.0 (Figs $2 \mathrm{~d}$ and 4), a thick leaf deposit at a depth of $80 \mathrm{~cm}$ is dated to $19.4 \pm 0.1 \mathrm{k}$ cal a BP. Wood from the same layer yielded an age of $19.5 \pm$ $0.1 \mathrm{k}$ cal a BP.

- At km 37.5 (Fig. 4) leaves at a depth of $100-120 \mathrm{~cm}$ below the surface are dated to $15.6 \pm 0.1 \mathrm{k}$ cal a BP.

- At km 37.7 (Figs 2e and 4), the profile consists of a volcanic ash layer and an organic layer at the bottom intercalated with stratified slope deposits. Approximately $110 \mathrm{~cm}$ below the surface, a dark, greyish palaeosol (bAh-horizon) indicates a period of relative surface stability at $15.4 \pm 0.4 \mathrm{k}$ cal a BP. It is directly overlain by leaves with an age of $16.1 \pm 0.1 \mathrm{k}$ cal a BP. Both the palaeosol horizon and the leaf layer are truncated by the palaeochannel of a gully or small creek. The palaeochannel is filled by stratified slope deposits without organic layers and is no longer visible at the surface.

In summary, all dated wood and leaf samples belong stratigraphically to the Upper Pleistocene between $\sim 15$ and $38 \mathrm{k}$ cal a BP. In all profiles, the lowermost layers are the oldest ones, becoming younger towards the surface. ${ }^{14} \mathrm{C}$ ages from leaves and wood from the same layer are in good accordance with this. No age inversions between layers occur. The results from ${ }^{14} \mathrm{C}$ dating of seven additional samples (Table 2), which were processed using two different methodologies, are internally consistent, and range between $\sim 16$ and $35 \mathrm{k}$ cal a BP. Hence, they corroborate the chronological results obtained from the other profiles.

\section{Discussion}

The modern upper limit of living trees ('treeline', Figs 3a and 5) is characterized by a zone of non-climatic struggle between valley floor vegetation that depends on the presence of perennial surficial water and groundwater in the Rio Lluta floodplain deposits, and the vegetation-bare hillslopes with extreme aridity and active gravitational processes, mainly surficial creep, induced by wetting and drying of salt (Abele, 1987, 1990). This seems to be the present-day process, reflecting the dry environmental conditions on the slopes. Small gullies, as in profile $\mathrm{km} 37.7$ (Fig. 2e), may have formed in a very short period, indicating linear erosion on the slope after $16.1-15.4 \mathrm{k}$ cal a BP. They are filled with stratified slope deposits, which formed under dry conditions, comparable to those of today. Thus, in the marginal floodplain and on the lowermost slopes, accumulating organic matter, leaves and wood debris are successively covered by sediments of salt-creep, ultimately forming stratified deposits of alternating organic material and slope debris. The distribution of these deposits including the fossil trees and leaves is restricted to the lowermost slopes $\sim 15-20 \mathrm{~m}$ above the modern floodplain in relative proximity to the modern treeline, indicating that the presence of fossilized vegetation remains does not reflect wetter climatic conditions at a local scale and extensively vegetated hillslopes, 
for example as the result from substantially increased precipitation. A wider distribution of organic material and related palaeosols could be expected if more humid climatic conditions had prevailed at low elevations in the Atacama Desert, but has not been observed in the numerous hillslope quarries. In combination with the clear dominance of tree taxa in the organic layers, and the lack of hillslope taxa in the fossil record, this implies a higher palaeo'treeline' (treeline A, Figs 3a and 5). In our profiles, the available radiocarbon dates from organic remains within the stratified slope deposits range between $\sim 38$ and $15.4 \mathrm{k}$ cal a BP and thus reflect tree growth up to $\sim 9 \mathrm{~m}$ above the modern 'treeline' for this timeframe. In contrast, the youngest and stratigraphically uppermost organic layers consistently date to $\sim 15.4 \mathrm{k}$ cal a BP, and no younger radiocarbon ages are available. Based on our model of quasi-continuous formation of stratified slope deposits along the marginal floodplain, this suggests a $\sim 9$-m downslope shift of the 'treeline' (from treeline A to B, Fig. 5) after $\sim 15.4 \mathrm{k}$ cal a BP in relation to a major drop of the valley floor at that time.

Several scenarios could explain this drop on the order of $\sim 9 \mathrm{~m}$ at our study site along the Rio Lluta: (i) the re-organization of the valley floor and river long-profile as the result of tectonics, (ii) the influence of global sea-level oscillations through the last glacial cycle, (iii) blocking of the valley by mass wasting (landslides, alluvial fans from tributaries, etc.) or dunes, (iv) reduced runoff and/or groundwater recharge in the Rio Lluta catchment due to drier climatic conditions in the Western Cordillera of the Andes, or - vice versa - (v) river incision induced by intensified runoff from the Western Cordillera and increased stream power.

Neotectonic activity is common throughout the Andean forearc and the Coastal Cordillera, even though the exact mechanisms and magnitudes of deformation related to stress accumulation and release during the seismic cycle are not yet fully understood (Allmendinger and González, 2010; A. Madella et al., unpubl. data). Marine terraces dating to $140 \mathrm{ka}$ are found up to $250 \mathrm{~m}$ a.s.l. in northen Chile and up to $300 \mathrm{~m}$ a.s.l. in southern Peru (Regard et al., 2010), indicating variable uplift rates of up to $2.1 \mathrm{~m} \mathrm{ka}^{-1}$. In the area immediately north of Arica at the mouth of the Rio Lluta, however, the Coastal Cordillera is absent (Fig. 1a). In contrast, the broad Rio Lluta-Tacna plain seems to indicate relative subsidence rather than uplift. However, the discovery of ca. 10 ka raised fluvial terraces directly at the mouth of the Rio Lluta does suggest the occurrence of uplift, at least at the coast (A. Madella et al., unpubl. data). Nevertheless, this uplift is unlikely to explain the 9-m lowering of groundwater table in the study reach because it occurred ca. 5000 years later. In addition, the study area is characterized by the lack of active structures (A. Madella et al., unpubl. data), which implies that the smooth slopes and related deposits that embed the fossil wood are not affected by any tectonic deformation. This observation indicates that a tectonic disturbance alone could not be the major control for the onset of incision in this area.

During the Last Glacial Maximum (LGM), global sea level was ca. 125-135 m lower than today (Sidall et al., 2006; Lambeck et al., 2014). Today, the valley floor at our study site is $\sim 750 \mathrm{~m}$ a.s.l. and up to $30-50 \mathrm{~km}$ inland from the coastline. The gradient at Poconchile is $\sim 25 \mathrm{~m} \mathrm{~km} \mathrm{~km}^{-1}$ and gradually decreases to $\sim 15 \mathrm{~m} \mathrm{~km}^{-1}$ along the coast. During the LGM sea-level lowstand, the coastline would have been $\sim 20 \mathrm{~km}$ west of the modern coastline (Becker et al., 2009), indicating even lower gradients of around $\sim 6 \mathrm{~m} \mathrm{~km}^{-1}$. Additionally, sea level approached the LGM lowstand gradually over the last glacial cycle, in combination probably limiting the potential for significant upstream migration of a knickpoint. In contrast, the postglacial rise of global sea level was rapid between 20 and $8 \mathrm{ka}$ with a particularly rapid increase around $15 \mathrm{ka}$ (Lambeck et al., 2014). As a consequence, upstream valley floor aggradation and a tendency of increasing water levels would be expected. However, our results clearly indicate a decrease in water levels and/or valley floor elevations, suggesting that sea-level changes were probably not a major control on the observed drop in treeline after 15k cal a BP, particularly considering that our study site is located at altitudes $>750 \mathrm{~m}$ a.s.l. The same holds true for a possible incursion of salinized groundwater and a corresponding lethal effect on the vegetation, following sea-level rise. This scenario cannot explain dying trees at $>750 \mathrm{~m}$ a.s.l.

Landslides or alluvial input from tributary rivers might have caused local blocking of the Lluta River. So far, no age control on visible landslides in the valley is available. Because fossil trunks and leaves exist from the coast, a few metres above sea level to far into the catchment up to $>1000 \mathrm{~m}$ a.s.l., and due 
to the complete lack of limnic sediments indicating former lake conditions, this catastrophic explanation does not seem realistic. Additionally, the vertical sequence of ${ }^{14} \mathrm{C}$ ages in the profiles would have to be interpreted as several blocking periods, with each (younger) one resulting in higher lake levels, which also has no indication in the sediments.

Pleistocene dunes might have blocked the Lluta River during periods of low sea level such as the LGM. The rising sea level after $15 \mathrm{ka}$ might have hindered new dune formation, allowing the Lluta River to incise into the valley bottom. However, as no major dune system has yet been be identified and datings are not available, these considerations are speculative. In addition and similar to the potential effect of landslide blocking, the dated profiles are situated at an altitude of $>750 \mathrm{~m}$ a.s.l., where a direct effect of blocking dunes in the lower part of the valley does not seem to be very likely.

The temporal coincidence between a well-known wet phase on the Altiplano and the initiation of valley lowering along the Rio Lluta suggests an environmental driver. In this context, some authors report wet LGM conditions in the Western Cordillera/Altiplano (e.g. Baker et al., 2001a,b; Bobs et al., 2001; Rigsby et al., 2005; Steffen et al., 2009). In turn, a drop in treeline after $15.4 \mathrm{k}$ cal a BP would consequently point to drier conditions. Most published proxies, however, point to wet climatic conditions on the Bolivian Altiplano, commonly referred to as the 'Tauca Period' (Servant and Fontes, 1978). Palaeolake Tauca was a freshwater lake, indicating enhanced precipitation between 18.1 and $14.1 \mathrm{k}$ cal a BP, with highest lake levels from 16.4 to $14.1 \mathrm{k}$ cal a BP (Servant and Fontes, 1978; Sylvestre et al., 1999; Placzek et al., 2006, 2013). Lake levels dropped after 14.1k cal a BP with a minor, secondary highstand during the minor Coipasa phase, between 13 and 11k cal a BP (Placzek et al., 2006). Nester et al. (2007) and Gayo et al. (2012) report perennial stream discharge in the endorheic basins of the Atacama (Pampa del Tamarugal, $19^{\circ} 30^{\prime}$ to $22^{\circ} \mathrm{S}$ ) between 16.4 and $13.7 \mathrm{k}$ cal a BP and consider this the most important groundwater recharge event of the past $18 \mathrm{ka}$. It might appear as a contradiction that the alluvial fans in the Pampa del Tamarugal reacted with aggradation, whereas the Río Lluta eroded and incised at the same time. However, this can be easily explained by the different geomorphological systems; the fans in the endorheic basins of the Atacama are generally inactive during dry periods. There, increased precipitation leads to erosion in the catchment and corresponding accumulation on the fans. In a perennial river system with a much larger catchment area like the Río Lluta, it depends on the balance between water energy and material transported to react with accumulation or incision. After 15.4k cal a BP, there was probably a more consistent and/or elevated discharge available to allow for incision. At the Río Salado catchment $\left(22^{\circ} \mathrm{S}\right)$, rodent middens from $3000 \mathrm{~m}$ a.s.l. have been interpreted as a two-fold precipitation increase at 17.5-16.3k cal a BP (Latorre et al., 2006). A number of palaeowetland deposits additionally point to a major wet phase between $>15$ and 9k cal a BP (Betancourt et al., 2000; Latorre et al., 2002, 2003; Rech et al., 2002, 2003; Quade et al., 2008). The regional climatic pattern reflected in all these records has been summarized as the 'Central Andean Pluvial Event' ('CAPE'; Quade et al., 2008). The onset of the CAPE (ca. 18k cal a BP) occurred 2000-2500 years before the lowering of the valley floor in the Lluta valley (15.4k cal a BP), as reflected in the youngest ages of the fossil leaves and trunks, but coincides well with the highstand of Lake Tauca and the wet period in the Pampa del Tamarugal at about 16.4-14k cal a BP. It is unlikely that fluvial incision at our study sites started at exactly the time when precipitation started to increase on the Altiplano. Instead, environmental changes in the catchment are progressively propagated through the fluvial system. This leads to a time lag (i.e. response time) which varies from catchment to catchment (compare e.g. Romans et al., 2016) and was probably 2000 years in duration after the onset of the CAPE in the Lluta Valley. Glacial ice modelling and dating of glacial advances also indicate rainfall increases of up to 100\% in the Central Andes during the Tauca period (Kull et al., 2002, 2008; Zech et al., 2007, 2008, 2010). In contrast, the preceding period before and around the LGM (44-17 ka) was probably cold and dry in this area, as inferred from the small number of middens and the widespread lack of wetland deposits of this age, and palaeobotanical studies on fossil plants contained in them (Latorre et al., 2002; Quade et al., 2008). 
In summary, the most plausible scenario for a 9-m drop in treeline is river incision and lowering of the valley floor after $15.4 \mathrm{k}$ cal a BP due to increased stream power and runoff from the Rio Lluta headwaters in the Western Cordillera and Altiplano, and corresponding to the highstand of the CAPE and Tauca wet phase.

\section{Conclusions}

Along the large valley systems in the hyperarid Atacama Desert of northern Chile, vegetation is markedly restricted to the floodplains and valley floors. As such, the treeline is non-climatic and is only indirectly controlled by precipitation via groundwater availability and humidity at the valley floor. Despite the notion of long-term climatic stability along the lower reaches of the Lluta River, the observation of fossil tree remains, leaves and organic material intercalated with slope deposits significantly above the modern treeline indicates a drop in treeline elevation. Our radiocarbon-based chronology for these organic deposits suggests that this drop occurred at $\sim 15.4 \mathrm{k}$ cal a BP, and was probably related to $\sim 9 \mathrm{~m}$ of incision triggered by a pulse of increased discharge during the CAPE, which was characterized by significantly increased tropical moisture and precipitation totals in much of the Central Andes.

Acknowledgments. We very much appreciate the intense review and the valuable comments made by two reviewers.

Abbreviations. CAPE, Central Andean Pluvial Event; LGM, Last Glacial Maximum.

\section{References}

Abbott MB, Wolfe BB, Wolfe AP et al. 2003. Holocene paleohydrology and glacial history of the central Andes using multiproxy lake sediment studies. Palaeogeography, Palaeoclimatology, Palaeoecology 194: 123-138 [DOI: 10.1016/S0031-0182(03)00274-8].

Abele G. 1987. Das Relief der Andenwestflanke bei Antofagasta (Nordchile) unter dem Einfluß langfristiger und extremer Trockenheit. Erdkunde 41: 299310 [DOI: 10.3112/erdkunde.1987.04.04].

Abele G. 1990. Salzkrusten, salzbedingte Solifluktion und Steinsalzkarst in der nordchilenisch-peruanischen Wüste. Mainzer Geographische Studien 34: 2346.

Allmendinger RW, González G. 2010. Invited review paper: Neogene to Quaternary tectonics of the coastal Cordillera, northern Chile. Tectonophysics 495: 93-110 [DOI: 10.1016/j.tecto.2009.04.019]. 
Alpers CN, Brimhall GH. 1988. Middle Miocene climatic change in the Atacama Desert, northern Chile: Evidence from supergene mineralization at La Escondida. Geological Society of America Bulletin 100: 1640-1656 [DOI: 10.1130/0016-7606(1988)100<1640:MMCCIT>2.3.CO;2].

Ariazza B. 1995. Chile's Chinchorro mummies. National Geographic 187: 68-89.

Baker PA, Rigsby CA, Seltzer GO et al. 2001b. Tropical climate changes at millennial and orbital timescales on the Bolivian Altiplano. Nature 409: 698-701 [DOI: 10.1038/35055524] [PubMed: 11217855],

Becker JJ, Sandwell DT, Smith WHF et al. 2009. Global bathymetry and elevation data at 30 arc seconds resolution: SRTM30_PLUS. Marine Geodesy 32: 355-371 [DOI: 10.1080/01490410903297766].

Baker PA, Seltzer GO, Fritz SC et al. 2001a. The history of South American tropical precipitation for the past 25,000 years. Science 291: 640-643 [DOI: 10.1126/science.291.5504.640] [PubMed: 11158674].

Betancourt JL, Latorre C, Rech JA et al. 2000. A 22,000-year record of monsoonal precipitation from northern Chile's Atacama Desert. Science 289: 15421546 [DOI: 10.1126/science.289.5484.1542] [PubMed: 10968788].

Bobs AL, Lowenstein TK, Jordan TE et al. 2001. A 106ka paleoclimate record from drill core of the Salar de Atacama, northern Chile. Palaeogeography, Palaeoclimatology, Palaeoecology 173: 21-42 [DOI: 10.1016/S0031-0182(01)00308-X].

Campos Ortega H, Díaz Muñoz G, Campos Ortega C. 2007. Aportes sedimentarios de los ríos Lluta y San José en la zona costera de la rada de Arica, Chile. Idesia 25: 37-48.

DGA. 2004. Cuenca del Río Lluta. Dirección General de Aguas, Gobierno de Chile.

Dunai TJ, González López GA, Juez-Larré J. 2005. Oligocene-Miocene age of aridity in the Atacama Desert revealed by exposure dating of erosion-sensitive landforms. Geology 33: 321-324 [DOI: 10.1130/G21184.1].

Durán-Gonzales JA, Cabrera-Fajardo G. 2001. Field determination of stream-aquifer interrelations caused by intensive groundwater pumping for water right purposes: integrated water resources management. IAHS Publication 272: 205-212.

Eitel B, Hecht S, Mächtle B et al. 2005. Geoarcheological evidence from desert loess in the Nazca-Palpa region, southern Peru: palaeoenvironmental changes and their impact on pre-Columbian cultures. Archaeometry 47: 137-158 [DOI: 10.1111/j.1475-4754.2005.00193.x].

Fritz SC, Baker PA, Lowenstein TK et al. 2004. Hydrologic variation during the last 170'000 years in the southern hemisphere tropics of South America. Quaternary Research 6: 95-104. 
García M, Hérail G. 2005. Fault-related folding, drainage network evolution and valley incision during the Neogene in the Andean Precordillera of Northern Chile. Geomorphology 65: 279-300 [DOI: 10.1016/j.geomorph.2004.09.007].

García M, Riquelme R, Farías M. 2011. Late Miocene-Holocene canyon incision in the western Altiplano, northern Chile: tectonic or climatic forcing? Journal of the Geological Society of London 168: 1047-1060.

Garreaud R, Vuille M, Clement AC. 2003. The climate of the Altiplano: observed current conditions and mechanisms of past changes. Palaeogeography, Palaeoclimatology, Palaeoecology 194: 5-22 [DOI: 10.1016/S0031-0182(03)00269-4].

Garreaud RD, Vuille M, Compagnucci R et al. 2009. Present-day South American climate. Palaeogeography, Palaeoclimatology, Palaeoecology 281: 180195 [DOI: 10.1016/j.palaeo.2007.10.032].

Gayo EM, Latorre C, Jordan TE et al. 2012. Late Quaternary hydrological and ecological changes in the hyperarid core of the northern Atacama Desert ( 21 ${ }^{\circ}$ S). Earth-Science Reviews 113: 120-140 [DOI: 10.1016/j.earscirev.2012.04.003].

Hogg AG, Hua Q, Blackwell PG et al. 2013. SHCal13 southern hemisphere calibration, 0-50,000 cal yr BP. Radiocarbon 55: $1889-1903$.

Houston J. 2006. Variability of precipitation in the Atacama Desert: its causes and hydrological impact. International Journal of Climatology 26: 2181-2198 [DOI: 10.1002/joc.1359].

Houston J, Hartley AJ. 2003. The Central Andean west-slope rainshadow and its potential contribution to the origin of hyper-aridity in the Atacama Desert. International Journal of Climatology 23: 1453-1464 [DOI: 10.1002/joc.938].

Jordan TE, Kirk-Lawlor NE, Blanco NP et al. 2014. Landscape modification in response to repeated onset of hyperarid paleoclimate states since 14 Ma, Atacama Desert, Chile. Geological Society of America Bulletin 126: 1016-1046 [DOI: 10.1130/B30978.1].

Kober F, Ivy-Ochs S, Schlunegger F et al. 2007. Denudation rates and a topography-driven rainfall threshold in northern Chile: multiple cosmogenic nuclide data and sediment yield budgets. Geomorphology 83: 97-120 [DOI: 10.1016/j.geomorph.2006.06.029].

Kull C, Grosjean M, Veit H. 2002. Modelling Modern and Late Pleistocene glacio-climatological conditions in the North Chilean Andes $\left(29^{\circ} \mathrm{S}-30^{\circ} \mathrm{S}\right)$. Climate Change 53: 359-381.

Kull C, Imhof S, Grosjean M et al. 2008. Late Pleistocene glaciation in the Central Andes: temperature versus humidity control - a case study from the eastern Bolivian Andes ( $\left.17^{\circ} \mathrm{S}\right)$ and regional synthesis. Global and Planetary Change 60: 148-164 [DOI: 10.1016/j.gloplacha.2007.03.011]. 
Lambeck K, Rouby H, Purcell A et al. 2014. Sea level and global ice volumes from the Last Glacial Maximum to the Holocene. Proceedings of the National Academy of Sciences of the United States of America 111: 15296-15303 [DOI: 10.1073/pnas.1411762111] [PubMed: 25313072].

Latorre C, Betancourt JL, Arroyo MTK. 2006. Late Quaternary vegetation and climate history of a perennial river canyon in the Río Salado basin (22 ${ }^{\circ}$ ) of Northern Chile. Quaternary Research 65: 450-466 [DOI: 10.1016/j.yqres.2006.02.002].

Latorre C, Betancourt JL, Rylander KA et al. 2002. Vegetation invasions into absolute desert: A 45;th000 yr rodent midden record from the Calama-Salar de Atacama basins, northern Chile (lat $22^{\circ}-24^{\circ} \mathrm{S}$ ). Geological Society of America Bulletin 114: 349-366 [DOI: 10.1130/00167606(2002)114<0349:VIIADA>2.0.CO;2].

Latorre C, Betancourt JL, Rylander KA et al. 2003. A vegetation history from the arid prepuna of northern Chile (22-23ㅇ) over the last 13500 years. Palaeogeography, Palaeoclimatology, Palaeoecology 194: 223-246 [DOI: 10.1016/S0031-0182(03)00279-7].

Lenters JD, Cook KH. 1997. On the origin of the Bolivian High and related circulation features of the South American climate. Journal of the Atmospheric Sciences 54: 656-678 [DOI: 10.1175/1520-0469(1997)054<0656:ОTOOTB>2.0.CO;2].

Lowenstein TK, Hein MC, Bobst AL et al. 2003. An assessment of stratigraphic completeness in climate-sensitive closed-basin lake sediments: Salar de Atacama, Chile. Journal of Sedimentary Research 73: 91-104 [DOI: 10.1306/061002730091].

Mortensen H. 1927. Der Formenschatz der nordchilenischen Wüste. Abhandlungen der Akademie der Wissenschaften in Göttingen, Math.-Physik. Kl., N.F. 12: $1-191$

Mortimer C, Sarič N. 1975. Cenozoic studies in northernmost Chile. Geologische Rundschau 64: 395-420.

Nester PL, Gayó E, Latorre C et al. 2007. Perennial stream discharge in the hyperarid Atacama Desert of northern Chile during the latest Pleistocene. Proceedings of the National Academy of Sciences of the United States of America 104: 19724-19729 [DOI: 10.1073/pnas.0705373104] [PubMed: 18056645].

Placzek C, Quade J, Patchett PJ. 2006. Geochronology and stratigraphy of late Pleistocene lake cycles on the southern Bolivian Altiplano: Implications for causes of tropical climate change. Geological Society of America Bulletin 118: 515-532 [DOI: 10.1130/B25770.1].

Placzek CJ, Quade J, Patchett PJ. 2013. A 130 ka reconstruction of rainfall on the Bolivian Altiplano. Earth and Planetary Science Letters 363: 97-108 [DOI: 10.1016/j.eps1.2012.12.017]. 
Quade J, Rech JA, Betancourt JL et al. 2008. Paleowetlands and regional climate change in the central Atacama Desert, northern Chile. Quaternary Research 69: 343-360 [DOI: 10.1016/j.yqres.2008.01.003].

Rech JA, Currie BS, Michalski G et al. 2006. Neogene climate change and uplift in the Atacama Desert, Chile. Geology 34: 761-764 [DOI: 10.1130/G22444.1].

Rech JA, Pigati JS, Quade J et al. 2003. Re-evaluation of mid-Holocene deposits at Quebrada Puripica, northern Chile. Palaeogeography, Palaeoclimatology, Palaeoecology 194: 207-222 [DOI: 10.1016/S0031-0182(03)00278-5].

Rech JA, Quade J, Betancourt JL. 2002. Late Quaternary paleohydrology of the central Atacama Desert (lat $22^{\circ}-24^{\circ}$ S), Chile. Geological Society of America Bulletin 114: 334-348 [DOI: 10.1130/0016-7606(2002)114<0334:LQPOTC>2.0.CO;2].

Regard V, Saillard M, Martinod J et al. 2010. Renewed uplift of the central Andes forearc revealed by coastal evolution during the Quaternary. Earth and Planetary Science Letters 297: 199-210 [DOI: 10.1016/j.epsl.2010.06.020].

Rigsby CA, Bradbury JP, Baker PA et al. 2005. Late Quaternary palaeolakes, rivers, and wetlands on the Bolivian Altiplano and their palaeoclimatic implications. Journal of Quaternary Science 20: 671-691 [DOI: 10.1002/jqs.986].

Romans BW, Castelltort S, Covault JA et al. 2016. Environmental signal propagation in sedimentary systems across timescales. Earth-Science Reviews 153: 7-29 [DOI: 10.1016/j.earscirev.2015.07.012].

Saillard M, Hall SR, Audin L et al. 2011. Andean coastal uplift and active tectonics in southern Peru: ${ }^{10} \mathrm{Be}$ surface exposure dating of differentially uplifted marine terrace sequences (San Juan de Marcona, 15.4 $\mathrm{S}$ ). Geomorphology 128: 178-190 [DOI: 10.1016/j.geomorph.2011.01.004].

Schildgen TF, Balco G, Shuster DL. 2010. Canyon incision and knickpoint propagation recorded by apatite ${ }^{4} \mathrm{He} /{ }^{3} \mathrm{He}$ thermochronometry. Earth and Planetary Science Letters 293: 377-387 [DOI: 10.1016/j.eps1.2010.03.009].

Schildgen TF, Hodges KV, Whipple KX et al. 2007. Uplift of the western margin of the Andean plateau revealed from canyon incision history, southern Peru. Geology 35: 523-526 [DOI: 10.1130/G23532A.1].

Schlunegger F, Zeilinger G, Kounov A et al. 2006. Scale of relief growth in the forearc of the Andes of Northern Chile (Arica latitude, 18oS). Terra Nova 18: 217-223 [DOI: 10.1111/j.1365-3121.2006.00682.x].

Schröder W, Wörner G. 1996. Widespread Cenozoic ignimbrites in N-Chile, W-Bolivia and S-Peru $\left(17^{\circ}-29^{\circ} \mathrm{S} / 71^{\circ}-68^{\circ} \mathrm{E}\right)$ : stratigraphy, extension, correlation and origin. 3me symposium international sur la Géeodynamique andine, Satin-Malo. ORSTOM Collection Colloques et Séminaires: 645-648. 
Schulz N, Boisier JP, Aceituno P. 2012. Climate change along the arid coast of northern Chile. International Journal of Climatology 32: 1803-1814 [DOI: 10.1002/joc.2395].

Servant M, Fontes JC. 1978. Les lacs quaternaires des hauts plateaux des Andes boliviennes. Premières interprétations paléoclimtaiques. Cahiers Orstom, Serie Geologie 10: 9-23.

Seyfried H, Wörner G, Uhlig D. 1995. Eine kleine Landschaftsgeschichte der Anden in Nordchile. Wechselwirkungen; Jahrbuch 1994: 60-72. University of Stuttgart.

Seyfried H, Wörner G, Uhlig D et al. 1998. Introducción a la geología y morfología de los Andes en el norte de Chile. Chungara 30: 7-39.

Sidall M, Chappell J, Potter EK. 2006. Eustatic sea-level during past interglacials. In The Climate of Past Interglacials, Sirocko F, Litt T, Claussen M, Sanchez-Goni MF (eds). Elsevier: Amsterdam; 75-92.

Steffen D, Schlunegger F, Preusser F. 2009. Drainage basin response to climate change in the Pisco valley, Peru. Geology 37: 491-494 [DOI: 10.1130/G25475A.1].

Strasser M, Schlunegger F. 2005. Erosional processes, topographic length-scales and geomorphic evolution in arid climatic environments: the 'Lluta collapse', northern Chile. International Journal of Earth Sciences 94: 433-446 [DOI: 10.1007/s00531-005-0491-2].

Stuiver M, Reimer PJ. 1993. Extended ${ }^{14} \mathrm{C}$ database and revised CALIB radiocarbon calibration program. Radiocarbon 35: 215-230.

Sylvestre F, Servant M, Servant-Vildary S et al. 1999. Lake-level chronology on the Southern Bolivian Altiplano (18 $\left.-23^{\circ} \mathrm{S}\right)$ during Late-Glacial Time and the Early Holocene. Quaternary Research 51: 54-66 [DOI: 10.1006/qres.1998.2017].

Szidat S, Salazar GA, Vogel E, Battaglia M, Wacker L, Synal HA, Türler A. 2014. ${ }^{14}$ C analysis and sample preparation at the New Bern Laboratory for the analysis of radiocarbon with AMS (LARA). Radiocarbon 56: 561-566 [DOI: 10.2458/56.17457].

Thouret J-C, Wörner G, Gunnell Y et al. 2007. Geochronologic and stratigraphic constraints on canyon incision and Miocene uplift of the Central Andes in Peru. Earth and Planetary Science Letters 263: 151-166 [DOI: 10.1016/j.eps1.2007.07.023].

Tobar A, Salas Y, Kast RF. 1968. Cuadrángulos Camarca y Azapa, Provincia de Tarapacá. Carta Geologica de Chile 19/20, 1:50 000, Inst. de Inv. Geológicas: Santiago.

Uhlig D. 1999. Die Westabdachung der Zentralanden in den Provinzen Arica und Parinacota, Nordchile: Landschaftsentwicklung und Geologie. Profil 17: 167-124. 
Vuille M. 1999. Atmospheric circulation over the Bolivian Altiplano during dry and wet periods and extreme phases of the Southern Oscillation. International Journal of Climatology 19: 1579-1600 [DOI: 10.1002/(SICI)1097-0088(19991130)19:14<1579::AID-JOC441>3.0.CO;2-N].

Vuille M, Bradley RS, Keimig F. 2000. Interannual climate variability in the Central Andes and its relation to tropical Pacific and Atlantic forcing. Journal of Geophysical Research: Atmospheres 105: 12447-12460 [DOI: 10.1029/2000JD900134].

Wörner G, Uhlig D, Kohler I et al. 2002. Evolution of the West Andean Escarpment at $18^{\circ} \mathrm{S}$ (N. Chile) during the last 25 Ma: uplift, erosion and collapse through time. Tectonophysics 345: 183-198 [DOI: 10.1016/S0040-1951(01)00212-8].

Zech J, Zech R, May JH et al. 2010. Lateglacial and Early Holocene glaciation in the tropical Andes caused by la Niña-like conditions. Palaeogeography, Palaeoclimatology, Palaeoecology 293: 248-254 [DOI: 10.1016/j.palaeo.2010.05.026].

Zech R, May J, Kull C et al. 2008. Timing of the late Quaternary glaciation in the Andes from $\sim 15$ to $40^{\circ}$ S. Journal of Quaternary Science 23: 635-647 [DOI: 10.1002/jqs.1200].

Zech R, Kull C, Kubik PW et al. 2007. Exposure dating of Late Glacial and pre-LGM moraines in the Cordon de Doña Rosa, Northern/Central Chile $\left(\sim 31^{\circ}\right.$ S). Climate of the Past 3: 1-14 [DOI: 10.5194/cp-3-1-2007].

Figure 1. Study area. (a) Overview; (b) northern Chile with morphotectonical units; (c) Lluta Valley with location of the study area; (d) location of studied profiles; (e) longitudinal profile of the Río Lluta. Triangle in (c) marks the location of dated wood at the coast, according to A. Madella (pers. comm.).

Figure 2. Field impressions from the Lluta Valley. (a) Overview, agriculture on the valley floor and dry slopes; (b-d) stratified slope deposits with intercalated wood and leaves; (e) gully, filled with slope deposits and older, buried organic soil horizons (note: green triangles mark organic layers with fossil trees, logs and leaves; white triangle marks volcanic ash).

Figure 3. Field impressions from the Lluta Valley. (a) Overview with palaeo-'treeline'; (b) organic layers in surface parallel position; (c) detail of leaf deposit; (d) leaves of dominating Escallonia angustifolia.

Figure 4. Sketch of profiles with ${ }^{14} \mathrm{C}$ dates. All dates are given as k cal a BP (Table 1).

Figure 5. Sketch, showing the evolution of the slopes and the valley bottom, the incision of the Río Lluta and the changes in 'treeline' due to lowering of the valley bottom.

Table $1 .{ }^{14} \mathrm{C}$ results from samples VEC $06 /$.

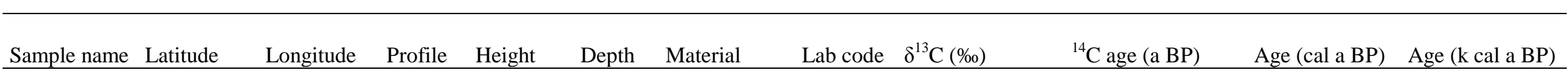




\begin{tabular}{|c|c|c|c|c|c|c|c|c|c|c|c|c|c|c|c|c|c|c|}
\hline & $\left({ }^{\circ} \mathrm{S}\right)$ & $\left({ }^{\circ} \mathrm{W}\right)$ & & $\begin{array}{l}\text { above } \\
\text { valley } \\
\text { floor }(\mathrm{m})\end{array}$ & $(\mathrm{cm})$ & & & & & & & & & & & & & \\
\hline VEC 06/35 & -18.40221 & -70.01646 & 36.2 & 12 & 80 & Leaves & B-9016 & -25.0 & \pm & 0.2 & 19870 & \pm & 70 & 23746 & 23993 & 23.9 & \pm & 0.1 \\
\hline VEC 06/39 & -18.40357 & -70.01371 & 36.5 & 11.5 & 15 & Reed & B-9012 & -10.2 & \pm & 0.2 & 510 & \pm & 20 & 503 & 520 & 0.5 & \pm & 0.0 \\
\hline VEC 06/36 & -18.40357 & -70.01371 & 36.5 & 11.5 & 50 & Leaves & B-9013 & -23.6 & \pm & 0.2 & 15120 & \pm & 90 & 18192 & 18459 & 18.3 & \pm & 0.1 \\
\hline VEC 06/37B & -18.40357 & -70.01371 & 36.5 & 11.5 & 120 & Leaves & B-9014 & -23.2 & \pm & 0.2 & 24900 & \pm & 100 & 28732 & 29001 & 28.9 & \pm & 0.1 \\
\hline VEC 06/38 & -18.40357 & -70.01371 & 36.5 & 11.5 & 250 & Wood & B-9015 & -24.4 & \pm & 0.2 & 33090 & \pm & 180 & 36733 & 37514 & 37.1 & \pm & 0.4 \\
\hline VEC 06/34A & -18.40553 & -70.00944 & 37.0 & 12.5 & 80 & Leaves & B-9010 & -23.4 & \pm & 0.2 & 16120 & \pm & 60 & 19298 & 19511 & 19.4 & \pm & 0.1 \\
\hline VEC 06/34B & -18.40553 & -70.00944 & 37.0 & 12.5 & 80 & Wood & B-9011 & -20.7 & \pm & 0.2 & 16180 & \pm & 60 & 19378 & 19583 & 19.5 & \pm & 0.1 \\
\hline VEC 06/33 & -18.40787 & -70.00493 & 37.5 & 13.5 & 110 & Leaves & B-9009 & -24.2 & \pm & 0.2 & 13080 & \pm & 70 & 15457 & 15757 & 15.6 & \pm & 0.2 \\
\hline VEC 06/30 & -18.40865 & -70.00325 & 37.7 & 13.5 & 115 & TOC fAh & B-9007 & -21.1 & \pm & 0.2 & 12930 & \pm & 220 & 15073 & 15782 & 15.4 & \pm & 0.4 \\
\hline VEC $06 / 32$ & -18.40865 & -70.00325 & 37.7 & 14 & 110 & Leaves & B-9008 & -23.4 & \pm & 0.2 & 13420 & \pm & 80 & 15973 & 16226 & 16.1 & \pm & 0.1 \\
\hline
\end{tabular}

Table 2. ${ }^{14} \mathrm{C}$ results from samples $\mathrm{LVW}$-, presented with $95 \%$ confidence limits.

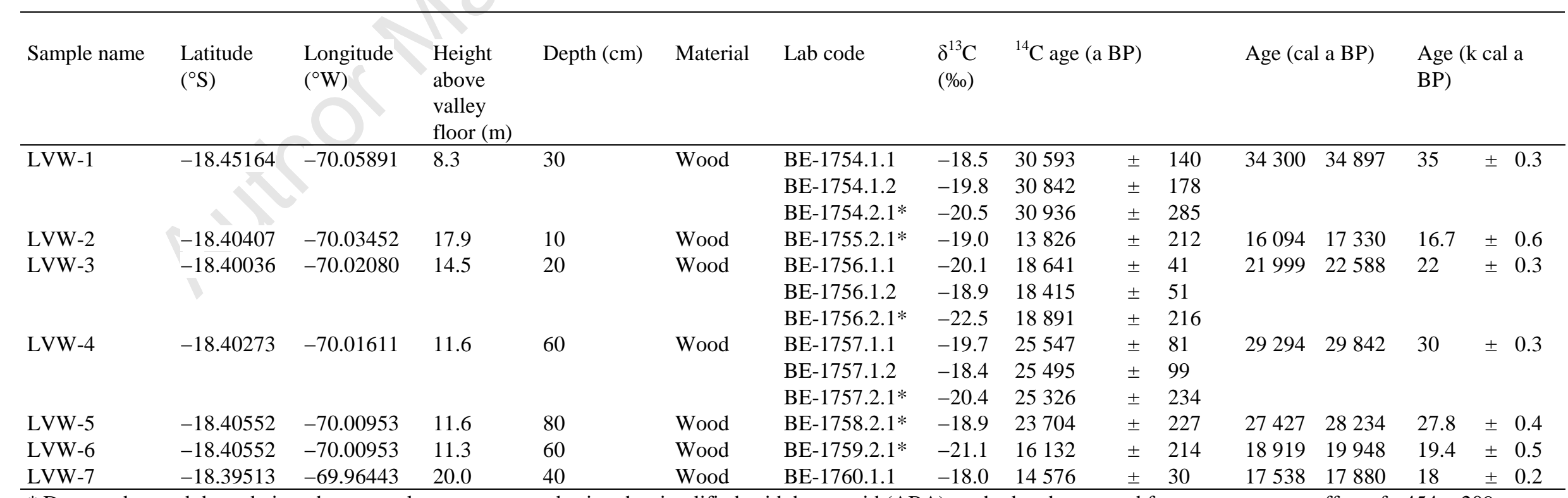

* Due to advanced degradation, these samples were prepared using the simplified acid-base-acid (ABA) method and corrected for an average age offset of $-454 \pm 209$ years

by comparison with the base-acid-base-acid-bleaching (BABAB) method, i.e. the standard method for wood analysis (Szidat et al., 2014). 


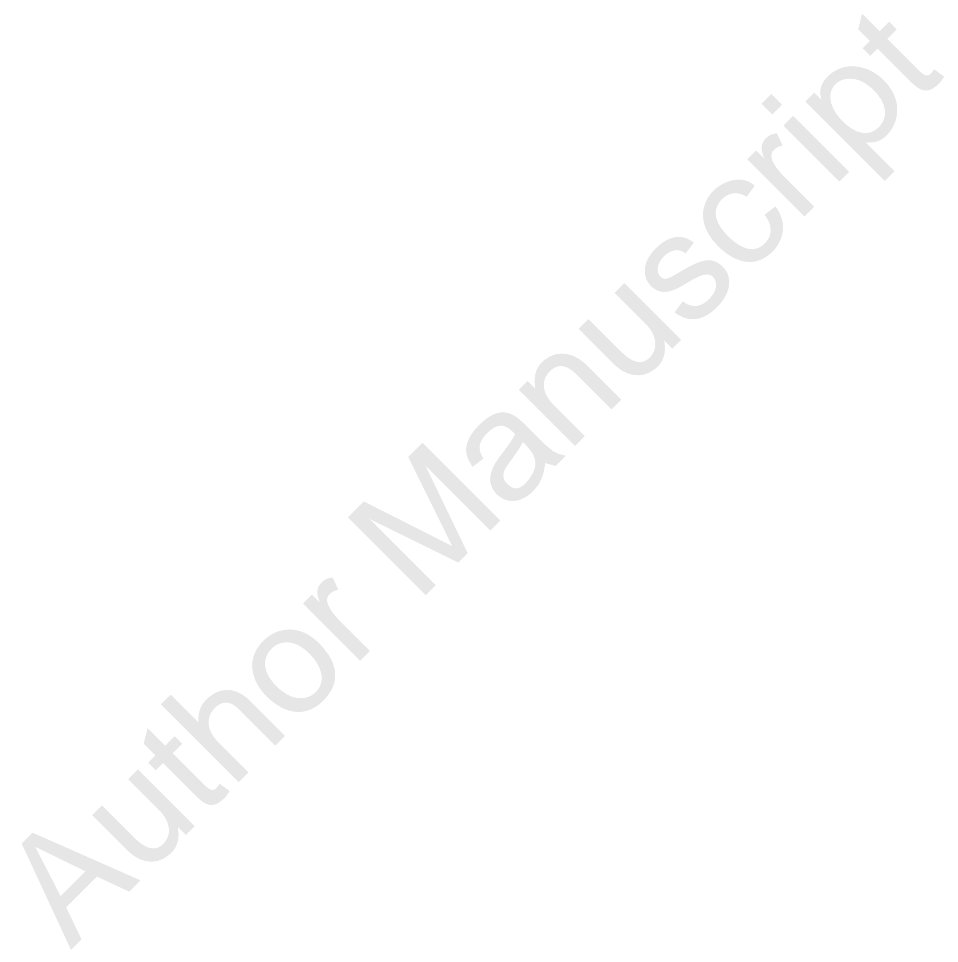



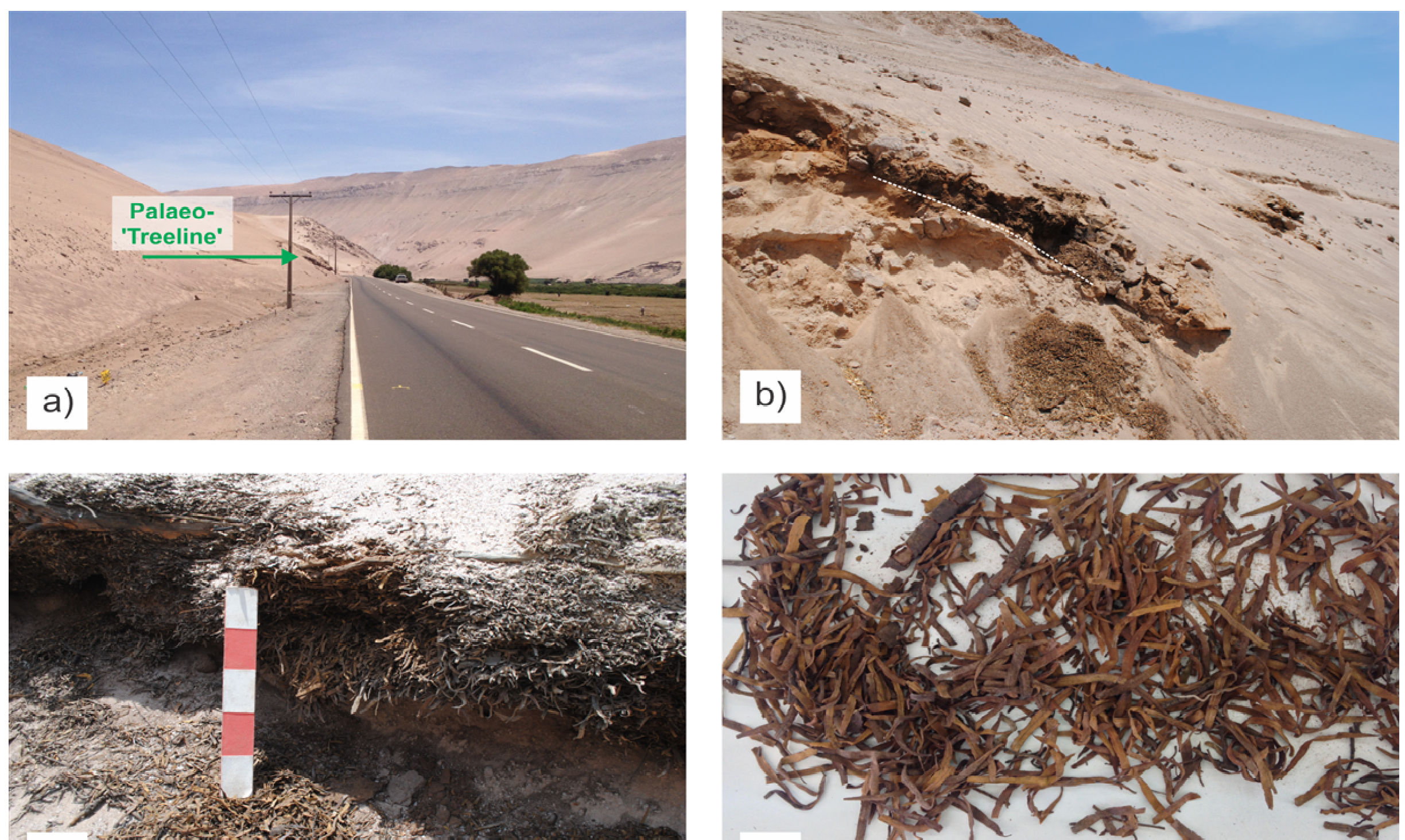

c)

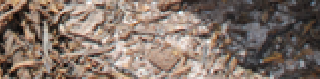

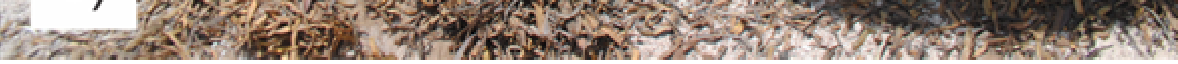

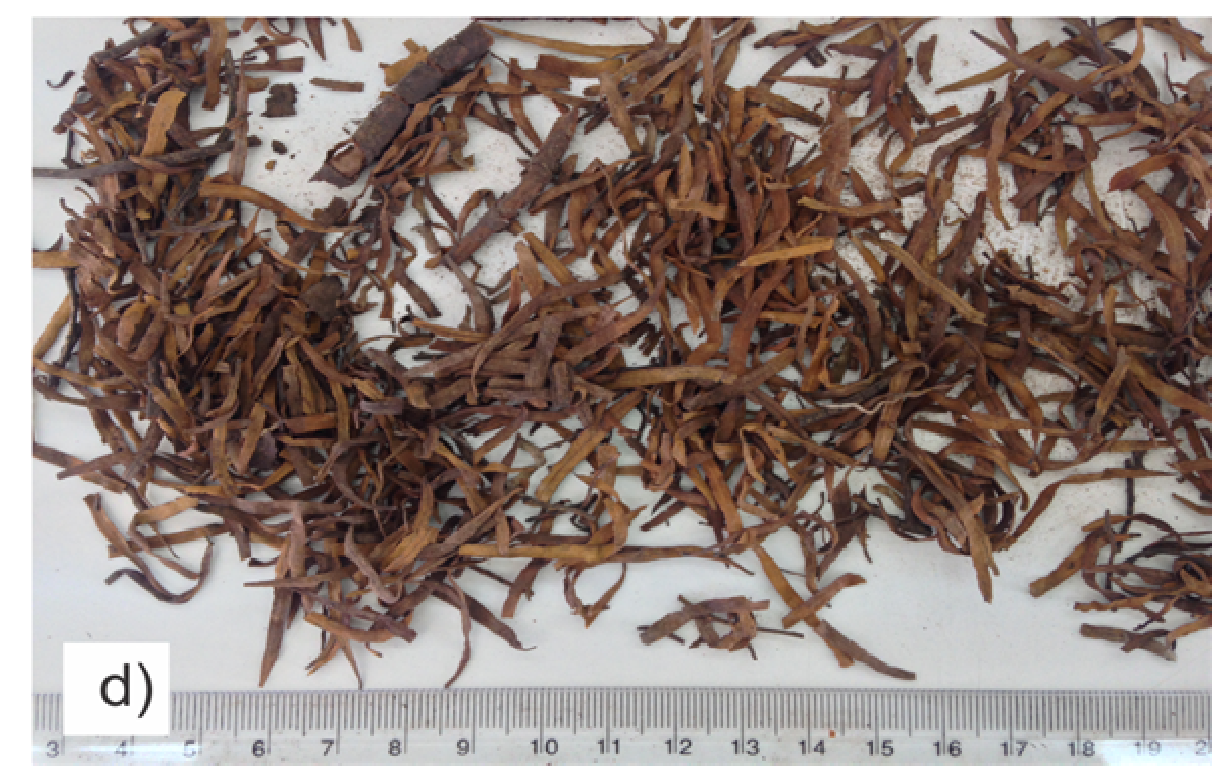


Fig 3

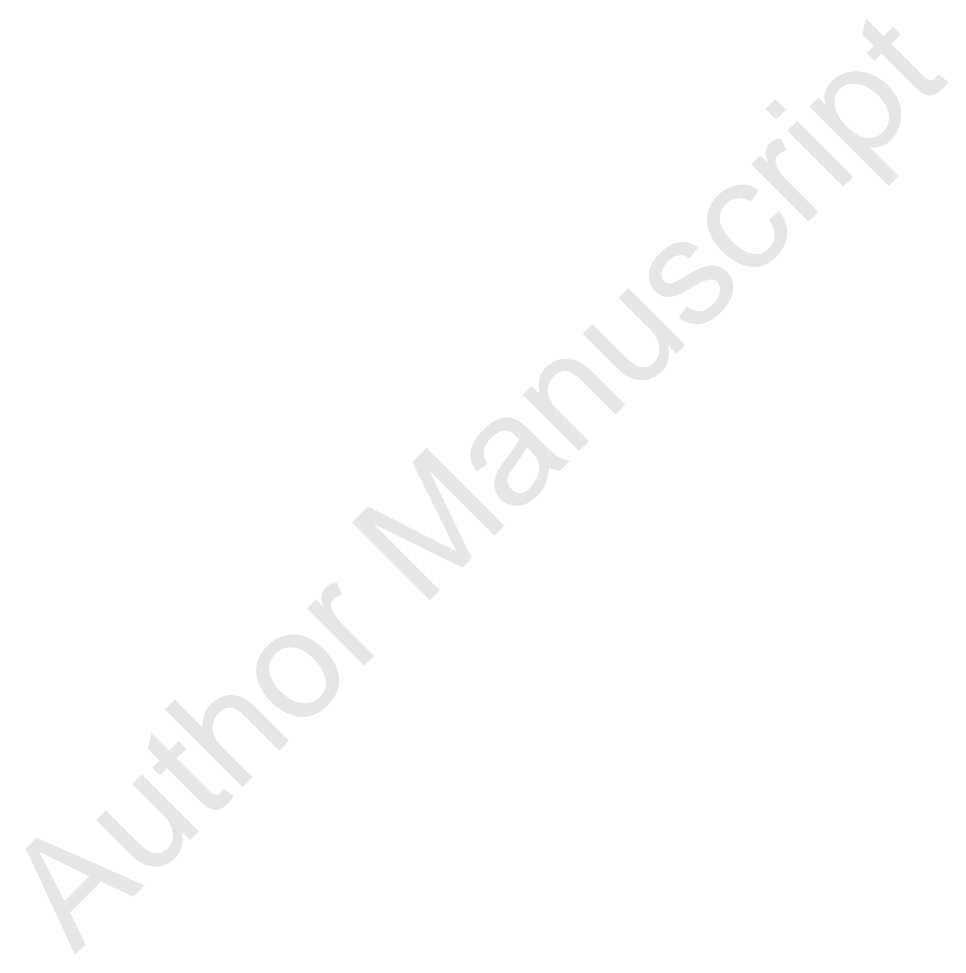



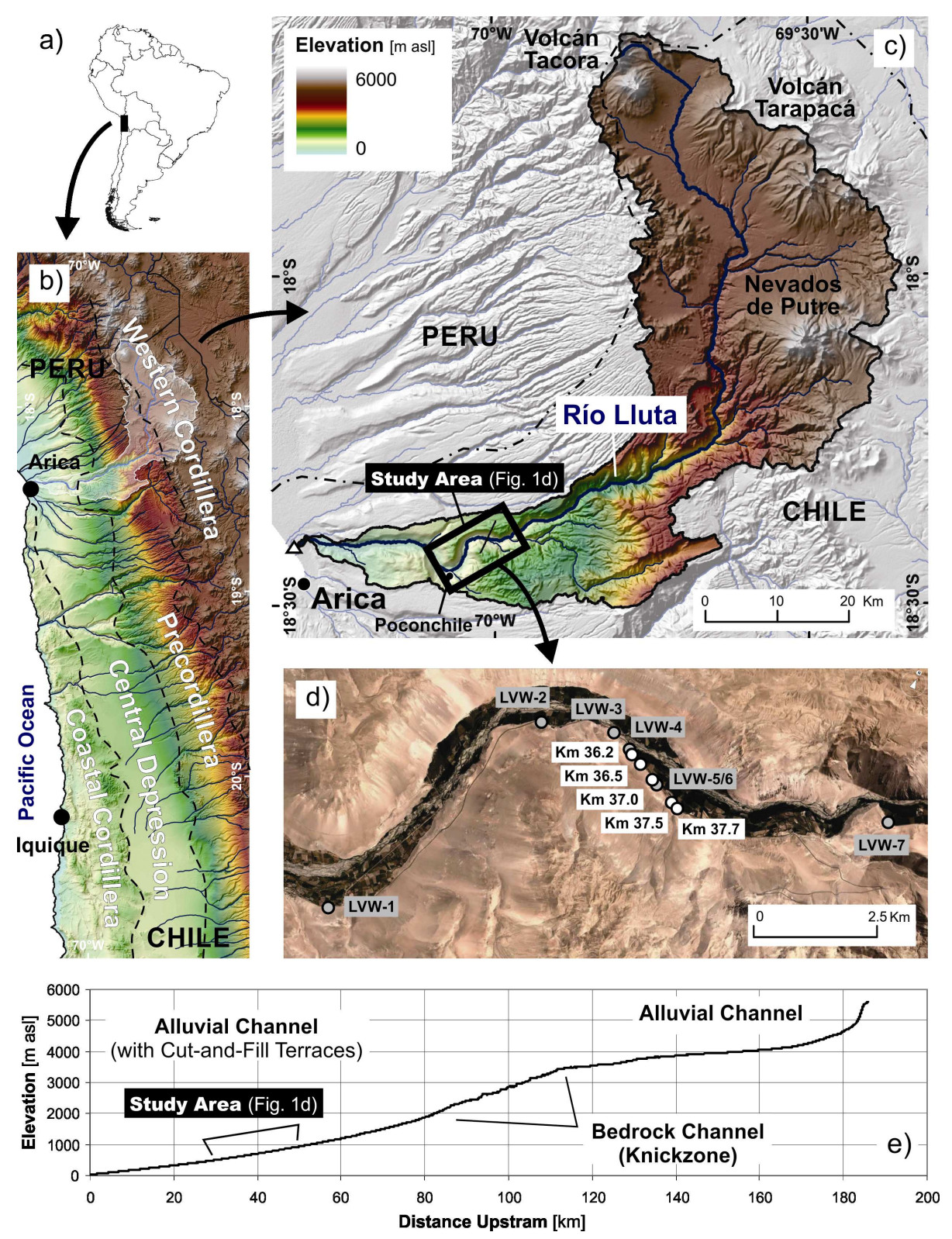


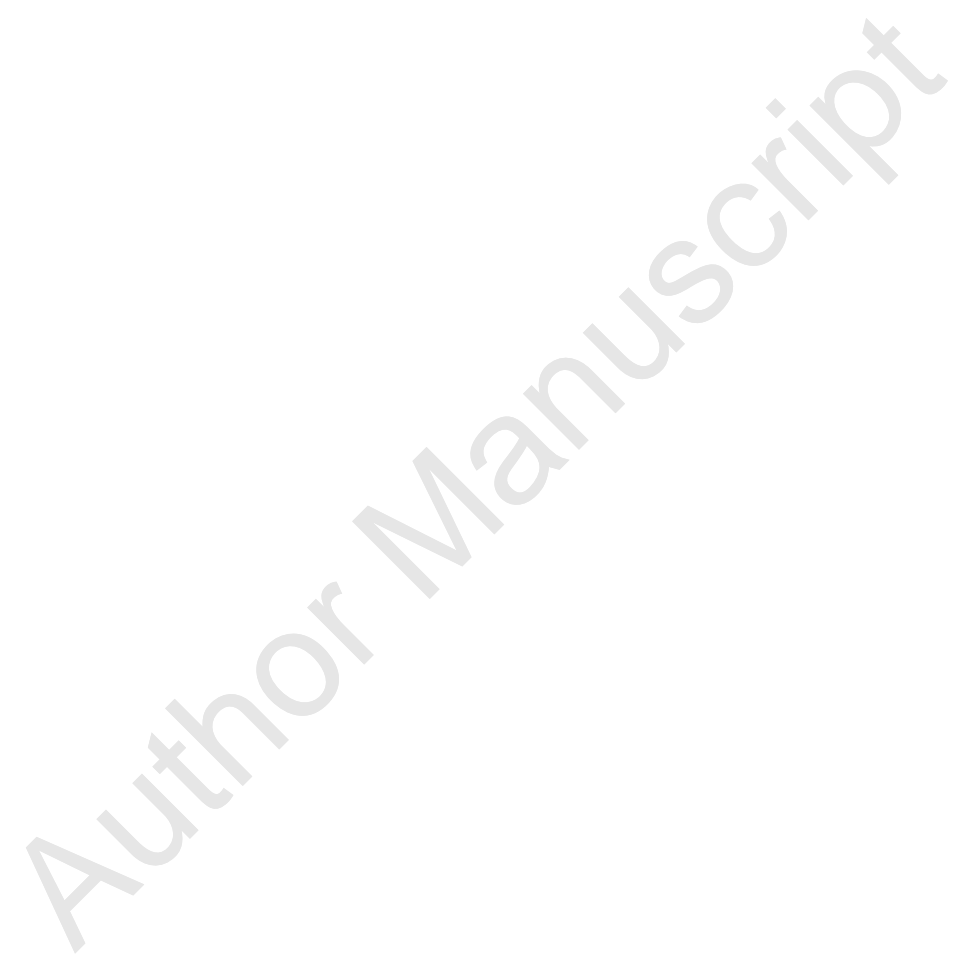



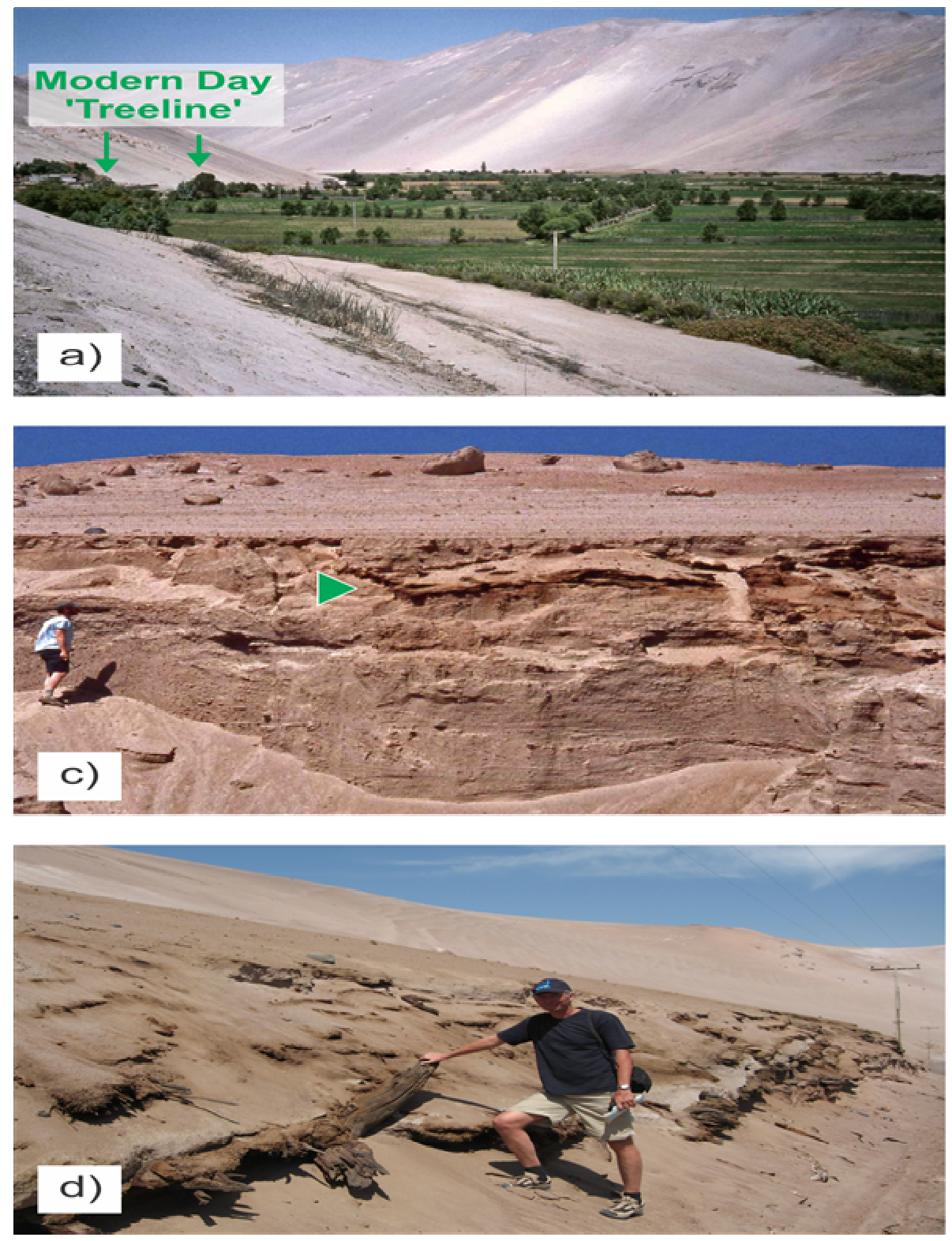
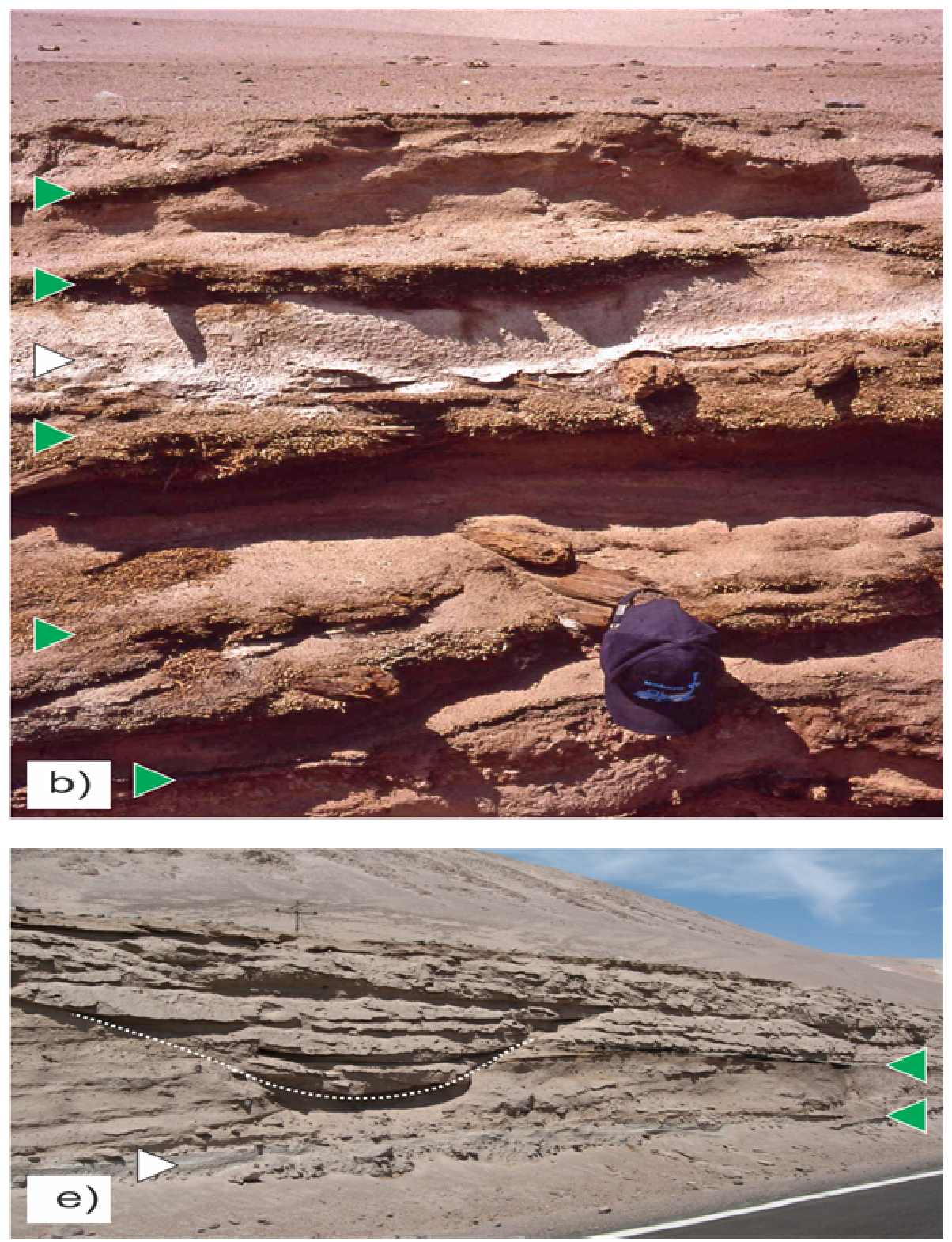
Fig2

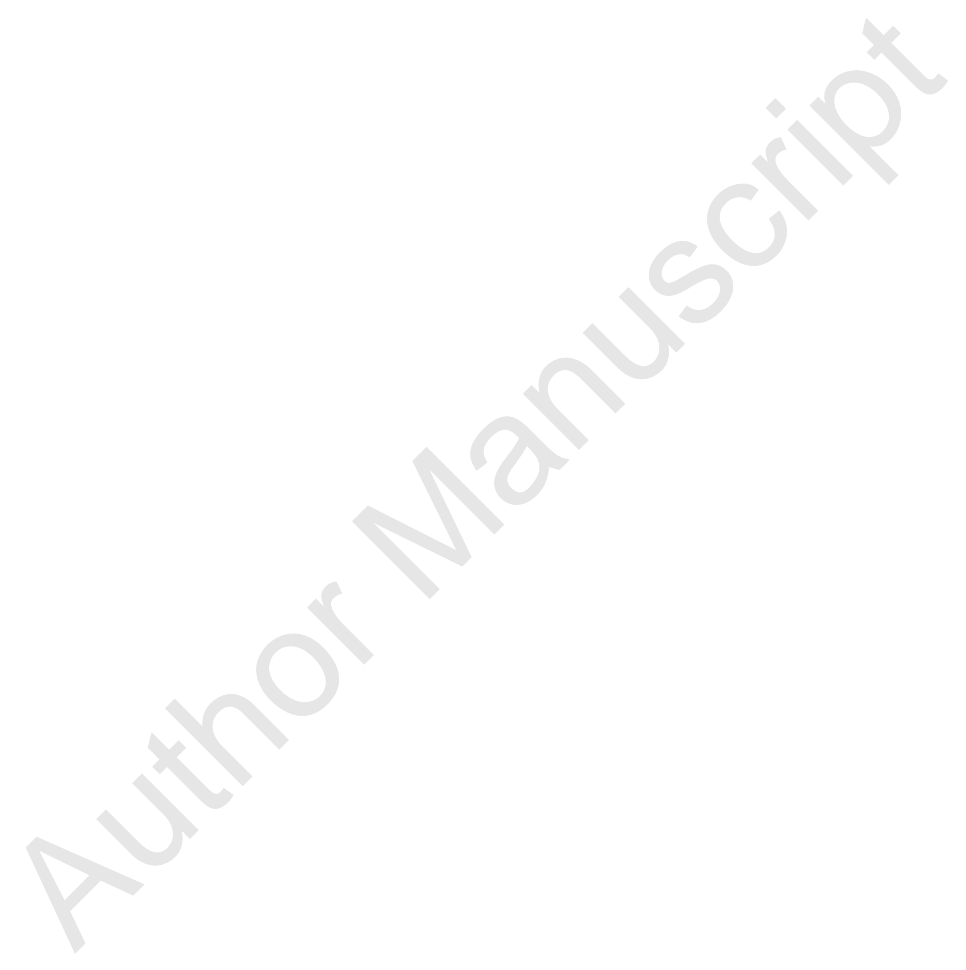


Profile 'km 36.2'

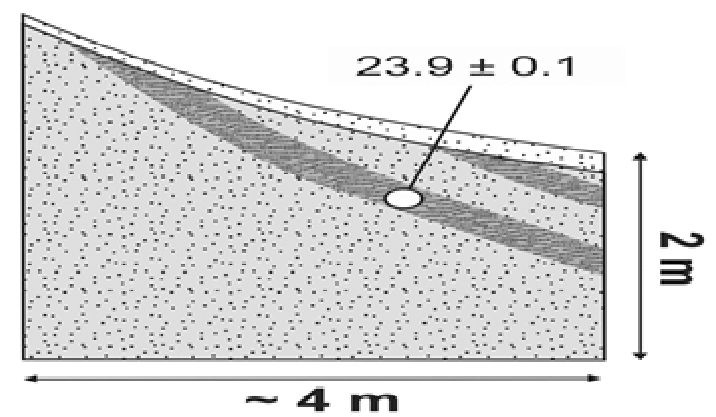

Profile 'km 37.0 '

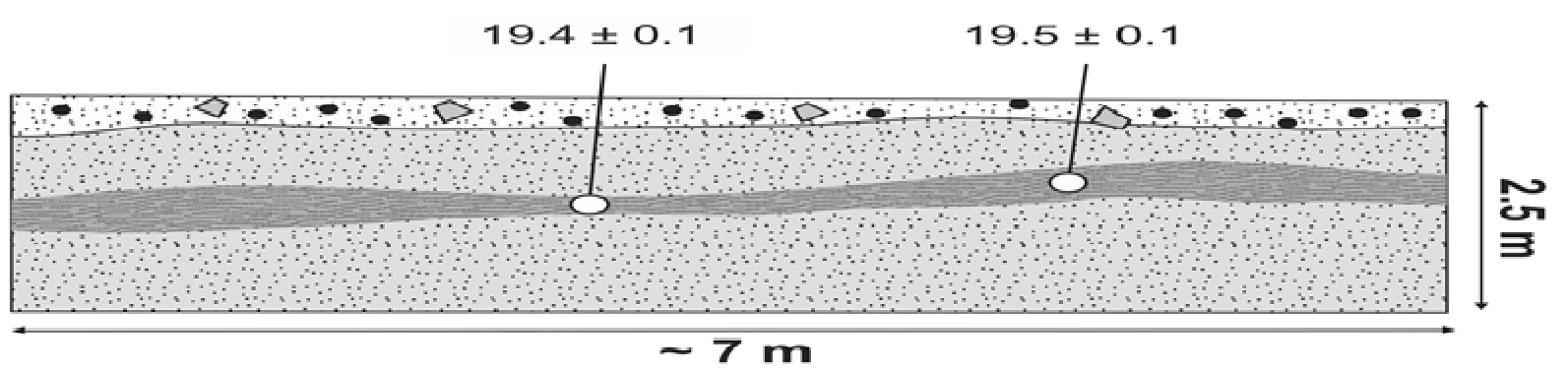

Profile 'km 36.5'

$18.3 \pm 0.1$

$28.9 \pm 0.1$

$37.1 \pm 0.4$

$0.5 \pm 0.0$

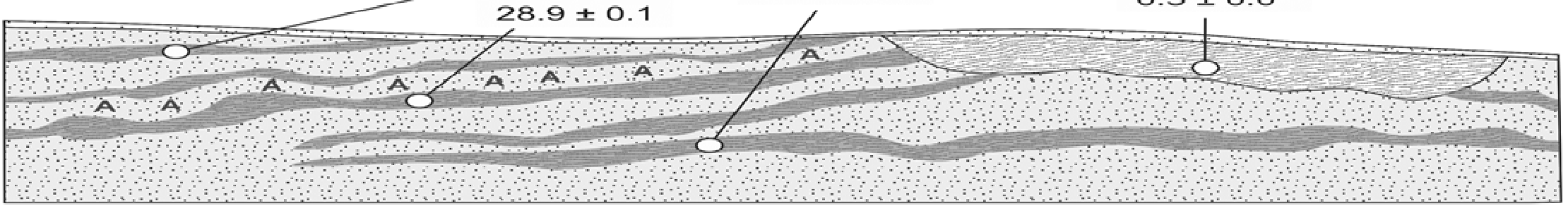

\section{Profile ' $\mathrm{km} 37.7$ '}

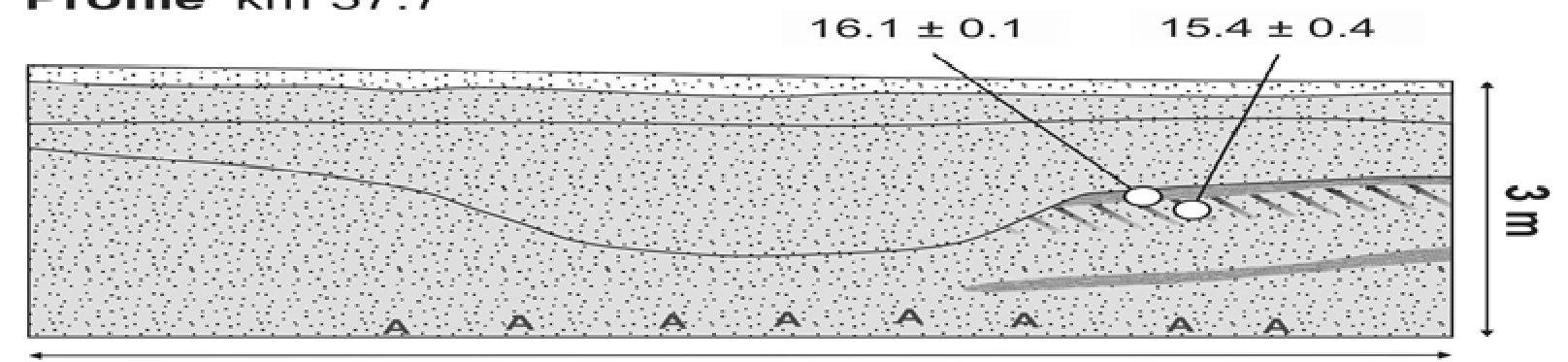

$\sim 20 \mathrm{~m}$

Profile 'km 37.5'

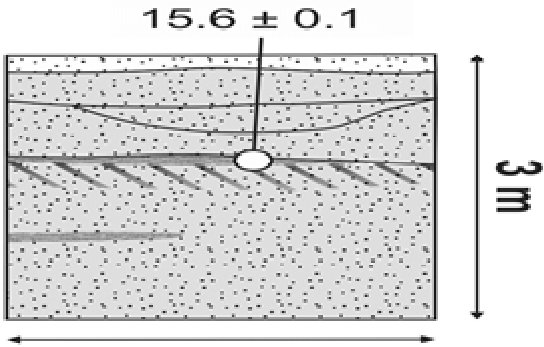

$-2 m$

\section{Legend}

[Late Holoene)

Plant Remains
(Wood, Leaves)
Pingins

\begin{tabular}{|l|}
\hline$A$ \\
\hline$A$
\end{tabular}

Paleosol

$\triangle \square$ Ceramics Volcanic Ash $\because$ : (Llama)

$0 \quad \begin{gathered}\text { Radiocarbon Age } \\ \text { (calke } \mathrm{BP} \text { ) }\end{gathered}$ 
Fig4

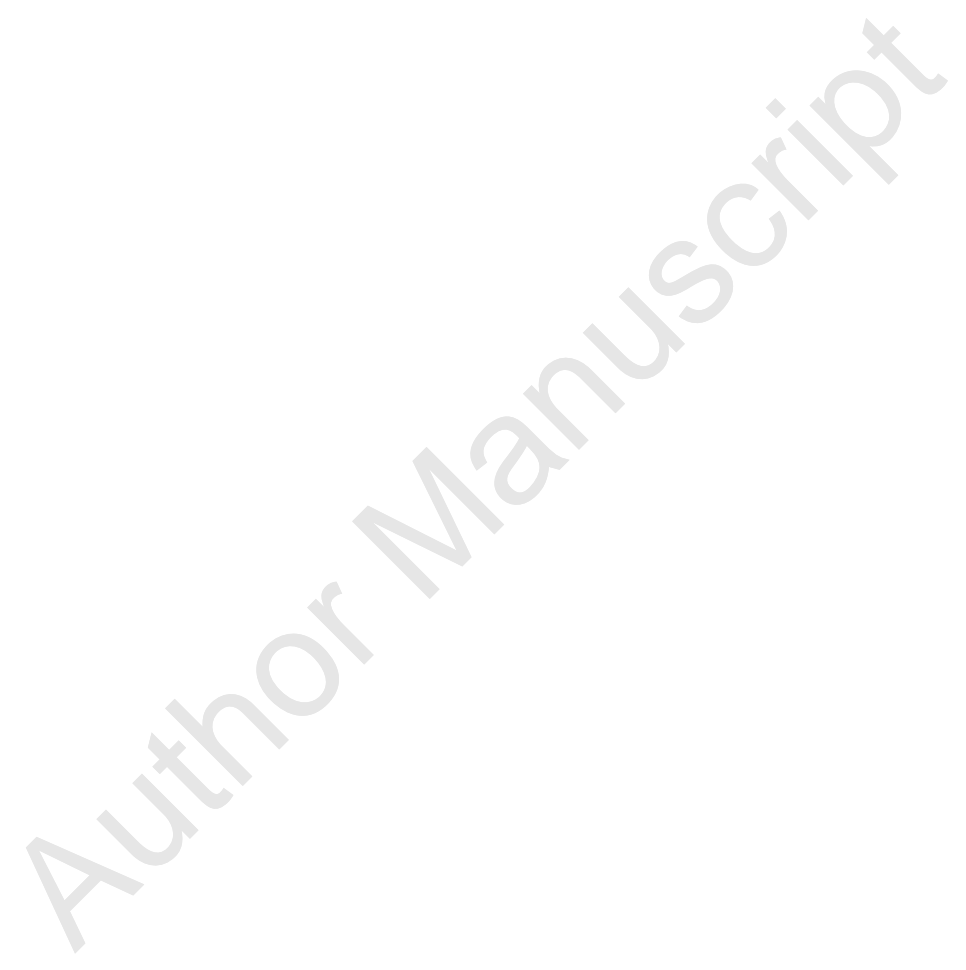




\section{a) $>38-15.4 \mathrm{cal}$ kyr BP}

1) Burial and Formation of Stratified Slope Deposits

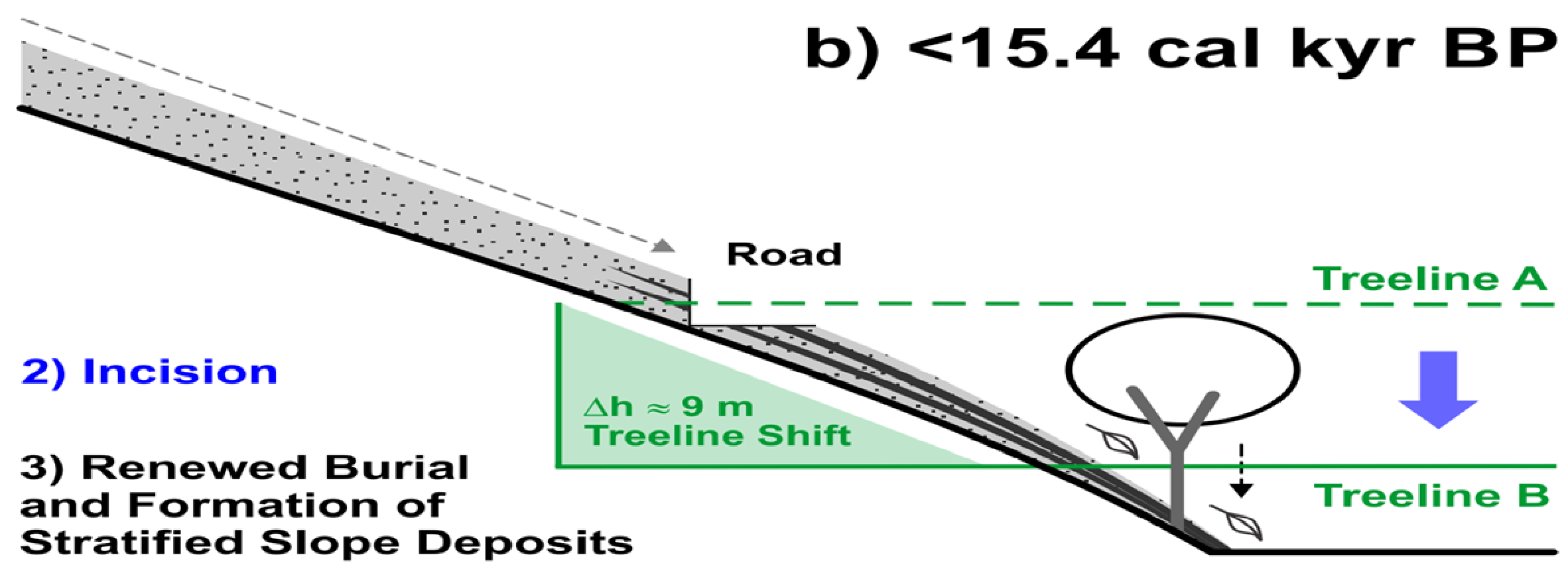


Fig5

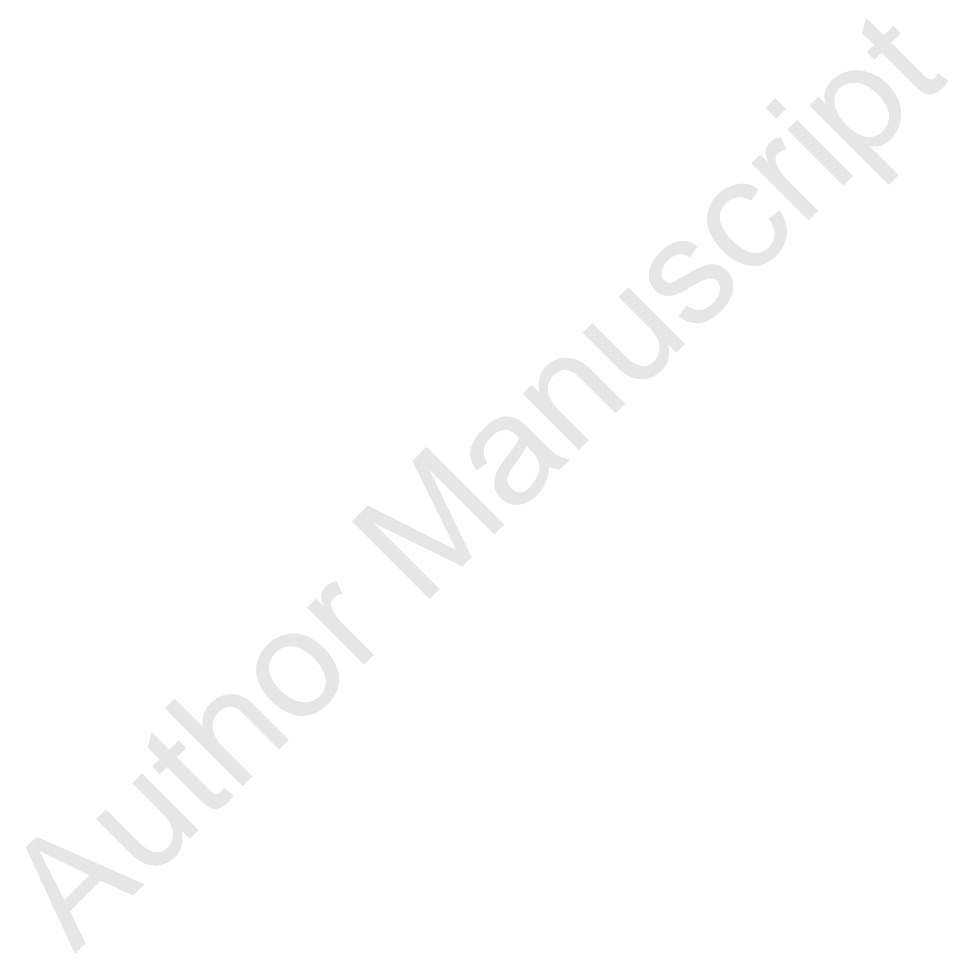




\section{University Library}

\section{- M M N E R VA A gateway to Melbourne's research publications}

Minerva Access is the Institutional Repository of The University of Melbourne

Author/s:

Veit, H;May, J-H;Madella, A;Delunel, R;Schlunegger, F;Szidat, S;Capriles, JM

Title:

Palaeo-geoecological significance of Pleistocene trees in the Lluta Valley, Atacama Desert

Date:

2016-04-01

Citation:

Veit, H., May, J. -H., Madella, A., Delunel, R., Schlunegger, F., Szidat, S. \& Capriles, J. M.

(2016). Palaeo-geoecological significance of Pleistocene trees in the Lluta Valley, Atacama

Desert. JOURNAL OF QUATERNARY SCIENCE, 31 (3), pp.203-213. https://doi.org/10.1002/ jqs.2857.

Persistent Link:

http://hdl.handle.net/11343/291136 